\title{
The Kinetics of Ethanol Fermentation Based on Adsorption Processes
}

DOI: 10.15255/KUI.2013.023

KUI-16/2014

Received August 17, 2013

Accepted November 19, 2013

\author{
Z. Liu* and X. Li \\ College of Chemical Engineering \& Pharmaceutics, Henan \\ University of Science and Technology, 471003 Luoyang, PR China
}

\begin{abstract}
Currently, almost all ethanol fermentation kinetic models are based on the Monod equation. Such models belong to empirical models, hence are not suitable for the optimization and expansion of real processes. In this work, a new ethanol fermentation kinetic model, in which all parameters had definite physical meaning, was established based on the adsorption mechanism. Through batch fermentation experiment with different initial glucose concentrations and comparison with existing model, this model has the advantage of high precision and few parameters. It also possessed obvious regulation in the model parameter that, with the increase in initial glucose concentration, the maximum specific growth rate $\mu_{\max }$ and adsorption equilibrium constant $K_{\mathrm{S}}$ of glucose decreased and adsorption equilibrium constant $K_{\mathrm{P}}$ of ethanol increased. This model provides a new perspective for kinetics research of fermentation.
\end{abstract}

Key words: Fermentation, biofuel, kinetics, biochemical engineering

\section{Introduction}

Currently, the oil crisis and serious environmental problems related to fossil fuels have caused the world to turn more attention toward biofuels production, especially ethanol fermentation from biomass. An appropriate kinetic model of ethanol fermentation would be a powerful instrument for fermentation efficiency increase and process optimization. The well-known Monod equation has been widely applied and modified to describe different fermentation processes. ${ }^{1-7}$ Unlike the Michaelis-Menten equation describing the mechanism of enzyme catalysis, the Monod equation is purely empirical with no mechanistic basis and hardly meets functional requirements to support large-scale production, process scale-up and optimization. In this paper, a simple kinetic model of ethanol fermentation is proposed, which provides a new perspective for kinetics research of fermentation.

\section{Model development}

Cell growth, substrate consumption, and product formation were taken into account in the developed kinetic model of ethanol fermentation. Most fundamental observations concerning cell growth were used to describe the behaviour of the given microbial system. The following first-order kinetic equation of cell growth was widely used:

$$
r_{\mathrm{x}}=\frac{\mathrm{d} \gamma_{\mathrm{x}}}{\mathrm{d} t}=\mu \gamma_{\mathrm{x}},
$$

\footnotetext{
*Corresponding author: Dr. Zhen Liu e-mail: liuz@haust.edu.cn
}

where $r_{x}$ denotes cell growth rate and $\gamma_{x}$ is cell concentration. The ideal expression of specific growth rate $\mu$ has been dominated by an empirical model originally proposed by Monod:

$$
\mu=\frac{\mu_{\max } \gamma_{\mathrm{S}}}{k_{\mathrm{S}}+\gamma_{\mathrm{S}}},
$$

where $k_{\mathrm{S}}$ is half-saturation coefficient and $\gamma_{\mathrm{S}}$ is glucose concentration. The microorganism can be also considered as a catalyst. Kinetic equation based on the catalysis theory in chemical engineering is generally in the form

$$
r_{\mathrm{x}}=K \gamma_{\mathrm{x}} \theta_{\mathrm{S}}
$$

where $K$ is the rate constant, and $\theta_{\mathrm{S}}$ is the fractional cell surface coverage with adsorbed glucose.

In the case of ethanol production by yeast cells, three essential steps were involved, including transportation of glucose into cells, glucose metabolism, as well as ethanol formation and passing through the membrane. Since glucose does not freely permeate biological membrane, its cellular uptake requires transporters to drive it across the membrane. The rate of sugar uptake in yeast cells is controlled by the glucose transportation. ${ }^{8}$ The facilitated transport of glucose moving into the cells is mediated by the reversible binding of glucose to the transport protein. This involves some kind of conformational change within the protein and neither substrates consumption nor chemical bonds making or breaking were found in this reversible process. The specific binding of glucose to the transporters can be considered as adsorption and 
$\theta_{\mathrm{S}}$ is assumed as the fraction of transporter on the surface of membrane to which glucose is adsorbed.

Owing to limitations of the classical Monod equation, an additional product inhibition term is present in general which is responsible for the delay in growth caused by the ethanol accumulation. $r_{\mathrm{x}}$ is given by Lun et al.: ${ }^{9}$

$$
r_{X}=\frac{\mu_{\max } \gamma_{S}}{k_{S}+\gamma_{S}} \frac{k_{P}}{k_{P}+\gamma_{P}}\left(1-\frac{\gamma_{P}}{\gamma_{P, \max }}\right) \gamma_{X},
$$

where $k_{\mathrm{p}}$ refers to the product inhibition constant, and $\gamma_{\mathrm{P}, \max }$ is the product concentration above which cells do not grow.

The exact mechanism of ethanol inhibition is yet to be fully understood. The reported proposal for the inhibition effects may result from the denaturation of glycolytic enzymes, damaging and altering membrane organizations, and inhibition of glucose, maltose, amino acid and ammonium transport, etc. ${ }^{10}$

The rate of glucose transport depends on the amount of the carrier available and the activity of transporters. ${ }^{11}$ The stability of transport protein is easily affected by the addition of ethanol, which is a protein conformation destabilizer, through the increment of protein secondary structure, disruption of protein native structure, and inducement of amyloid formation. ${ }^{12}$ The transport can be blocked by ethanol due to the denaturation of protein through the formation of competitive bonds between the alcohol and the non-polar residues of the protein, and results in the inhibition of glucose fermentation. Thereby, the transporters in the yeast cell membrane can be divided into three parts: transporters occupied by glucose $\left(\theta_{\mathrm{S}}\right)$, transporters occupied by ethanol $\left(\theta_{\mathrm{p}}\right)$, and free transporters $\left(\theta_{\vee}\right)$. The value of $\theta_{\mathrm{S}}$ can be calculated according to the Langmuir adsorption model.

It can be assumed that the adsorption of glucose $(G)$ and ethanol (E) to the transporters ( $\sigma$ ) occurred simultaneously.

$$
\mathrm{G}+\mathrm{E}+2 \sigma \underset{k_{d}}{\stackrel{k_{a}}{\rightleftharpoons}} \mathrm{G} \sigma+\mathrm{E} \sigma \text {. }
$$

The adsorption rate varied directly with substance concentration and the fraction of free transporters on the surface of membrane $\left(\theta_{v}=1-\theta_{S}-\theta_{\mathrm{p}}\right)$. The desorption rate of glucose or ethanol is directly related to the value of $\theta_{\mathrm{S}}$ or $\theta_{\mathrm{p}}$. Consequently, the glucose adsorption rate $\left(r_{\mathrm{as}}\right)$ and desorption rate $\left(r_{d s}\right)$ can be represented as follows:

$$
\begin{gathered}
r_{\mathrm{aS}}=k_{\mathrm{aS}} \gamma_{\mathrm{S}}\left(1-\theta_{\mathrm{S}}-\theta_{\mathrm{P}}\right), \\
r_{\mathrm{dS}}=k_{\mathrm{dS}} \theta_{\mathrm{S}},
\end{gathered}
$$

where $k_{\mathrm{as}}$ is the adsorption constant of glucose, $k_{\mathrm{ds}}$ is the desorption constant of glucose.

The adsorption rate $\left(r_{\mathrm{aP}}\right)$ and desorption rate $\left(r_{\mathrm{dP}}\right)$ of ethanol could be expressed by:

$$
r_{\mathrm{aP}}=k_{\mathrm{aP}} \gamma_{\mathrm{P}}\left(1-\theta_{\mathrm{S}}-\theta_{\mathrm{P}}\right)
$$

$$
r_{\mathrm{dP}}=k_{\mathrm{dP}} \theta_{\mathrm{P}},
$$

where $k_{\mathrm{ap}}$ and $k_{\mathrm{dp}}$ are the adsorption constant and desorption constant of ethanol, respectively.

When adsorption of glucose or ethanol reached equilibrium, the net adsorption rate is zero.

$$
\begin{aligned}
& r_{\mathrm{aS}}=r_{\mathrm{dS}} \\
& r_{\mathrm{aP}}=r_{\mathrm{dP}}
\end{aligned}
$$

Combining Eqs. 6-11 gives:

$$
\begin{aligned}
& \theta_{\mathrm{S}}=\frac{K_{\mathrm{S}} \gamma_{\mathrm{S}}}{1+K_{\mathrm{S}} \gamma_{\mathrm{S}}+K_{\mathrm{P}} \gamma_{\mathrm{P}}}, \\
& \theta_{\mathrm{P}}=\frac{K_{\mathrm{P}} \gamma_{\mathrm{P}}}{1+K_{\mathrm{S}} \gamma_{\mathrm{S}}+K_{\mathrm{P}} \gamma_{\mathrm{P}}},
\end{aligned}
$$

where $K_{\mathrm{S}}$ is the adsorption equilibrium constant of glucose and was expressed as $K_{\mathrm{s}}=k_{\mathrm{as}} / k_{\mathrm{ds}}$. $K_{\mathrm{p}}$ is the adsorption equilibrium constant of ethanol and was expressed as $K_{\mathrm{P}}=k_{\mathrm{aP}} / k_{\mathrm{dP}}$.

The complete kinetic equation accounting for ethanol inhibition is obtained by merging Eq. 12 and Eq. 3.

$$
r_{\mathrm{x}}=k \frac{K_{\mathrm{s}} \gamma_{\mathrm{S}}}{1+K_{\mathrm{S}} \gamma_{\mathrm{S}}+K_{\mathrm{P}} \gamma_{\mathrm{P}}} \gamma_{\mathrm{X}}
$$

Here $k$ can be designated as $\mu_{\max }$ which leads to the common form of kinetic equation.

$$
r_{\mathrm{X}}=\mu_{\max } \frac{K_{\mathrm{S}} \gamma_{\mathrm{S}}}{1+K_{\mathrm{S}} \gamma_{\mathrm{S}}+K_{\mathrm{P}} \gamma_{\mathrm{P}}} \gamma_{\mathrm{X}} .
$$

This equation appears totally different from the usual kinetic equations for cell cultures due to the simultaneous presence of $\gamma_{S}$ and $\gamma_{P}$ in the denominator.

If the impact of ethanol on the transporter is omitted, Eq. 14 becomes

$$
r_{\mathrm{x}}=k \frac{K_{\mathrm{S}} \gamma_{\mathrm{S}}}{1+K_{\mathrm{S}} \gamma_{\mathrm{S}}} \gamma_{\mathrm{x}}=\frac{k \gamma_{\mathrm{S}}}{\frac{1}{K_{\mathrm{S}}}+\gamma_{\mathrm{S}}} \gamma_{\mathrm{x}} .
$$

It is in accordance with the Monod equation, and indicates that the kinetic pattern of microorganisms can be explained by the adsorption mechanism as well.

For verification, the proposed model was applied to batch 
ethanol fermentation by yeast subjected to simulate the kinetic pattern and compared with the fermentation profiles and prediction of the classic model as Eq. 4.

Since the product of ethanol fermentation is related to cell growth, the ethanol production rate and substrate consumption rate are given by Lee et al..$^{13}$

$$
\begin{aligned}
& r_{\mathrm{P}}=\frac{r_{\mathrm{X}}}{Y_{\mathrm{X} / \mathrm{P}}} \\
& r_{\mathrm{S}}=\frac{r_{\mathrm{X}}}{Y_{\mathrm{X} / \mathrm{S}}},
\end{aligned}
$$

where, $r_{\mathrm{S}}$ and $r_{\mathrm{P}}$ are glucose consumption rate and ethanol formation rate, respectively. $Y_{\mathrm{X} / \mathrm{S}}$ is yield coefficient of biomass on glucose and $Y_{\mathrm{X} p \mathrm{P}}$ is yield coefficient of biomass on ethanol.

\section{Experiments}

Commercial ethanol instant active dry yeast (Saccharomyces cerevisiae) was used in this study, which was purchased from Angle Yeast Co., Ltd. Experiments were carried out to study the kinetics of batch fermentation of yeast at $35^{\circ} \mathrm{C}$ in a Biotech-5BG fermentor (Shanghai Baoxin Bioengineering Equipment CO., LTD.), which was agitated by a magnetic stirrer at $200 \mathrm{rpm}$ and controlled at $\mathrm{pH}$ 5.0. For preparation of yeast inoculum, $1 \mathrm{~g}$ dry yeast was added to $20 \mathrm{ml}$ sterile water containing $2 \%$ glucose, and incubated at $37^{\circ} \mathrm{C}$ for $1 \mathrm{~h}$. The inoculum concentration was $1 \mathrm{gl}^{-1}$. The experiments were conducted with various initial glucose concentrations of $110 \mathrm{gl}^{-1}, 160 \mathrm{gl}^{-1}$, and $220 \mathrm{gl}^{-1}$ respectively. The culture medium was composed of $3 \mathrm{~g} \mathrm{I}^{-1}$ yeast extraction, $5 \mathrm{~g} \mathrm{l}^{-1}$ $\mathrm{KH}_{2} \mathrm{PO}_{4}, 2 \mathrm{gl}^{-1}\left(\mathrm{NH}_{4}\right)_{2} \mathrm{SO}_{4}, 0.2 \mathrm{gl}^{-1} \mathrm{MgSO}_{4}$, and $0.1 \mathrm{gl}^{-1}$ $\mathrm{CaCl}_{2}$. All the reagents used in this study were of AR grade. All experimental data were the average of duplicate results, with variation smaller than $\pm 5 \%$.

Ethanol concentration was determined by HP4890D gas chromatography. Glucose concentration was measured by the dinitrosalicylic (DNS) colorimetric method. Biomass concentration was measured as optical density at $640 \mathrm{~nm}$ by interpolation from a pre-established dry weight calibration curve.

\section{Results and discussion}

Parameters in the kinetic model were estimated by nonlinear least-squares regression of the experimental data using Isqnonlin function in Matlab. Figs. 1-3 represent the simulations for cell growth, glucose consumption, and ethanol production during batch culture carried out by the classic model (Eq. 4) and the proposed model (Eq. 15). The required parameters in kinetic equations were calculated and are listed in Table 1. Simulated results indicated that, when the initial concentrations of glucose were $110 \mathrm{gl}^{-1}$ and $160 \mathrm{gl}^{-1}$, both models could satisfactorily simulate the fermentation pattern. Furthermore, the values of parameters $Y_{\mathrm{X} / \mathrm{P}}$ and $Y_{\mathrm{X} / \mathrm{s}}$ predicted from the two models are very close to each other. When the initial concentration of glucose reached $220 \mathrm{gl}^{-1}$, the difference between the experimental data and the pre- dicted value increased and turned out to be significant. It is probably due to the high substrate inhibition which was not included in both models. But considering that such high level of glucose is too high for practical purposes, the proposed model is much more useful for the optimization of ethanol batch fermentations by yeast compared with the classic model, because of its lower value of calculated residues, higher accuracy of prediction, and less parameters involved.

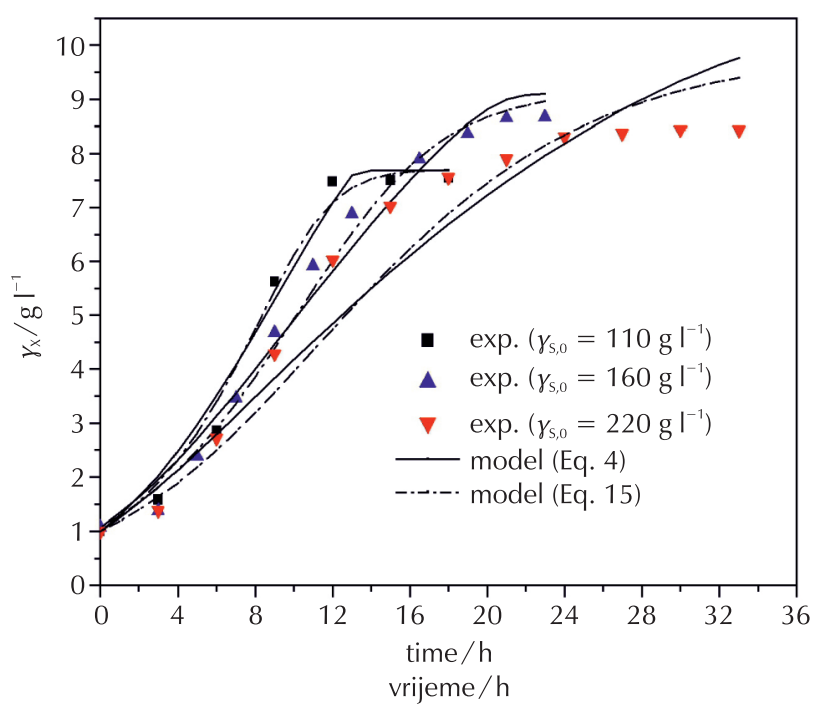

Fig . 1 - Experimental results and simulation of cell concentration at different initial concentrations of glucose $\left(110 \mathrm{gl}^{-1}, 160 \mathrm{gl}^{-1}\right.$, and $\left.220 \mathrm{gl}^{-1}\right)$

S I i k a 1 - Eksperimentalni rezultati i modeliranje koncentracije stanica pri različitim početnim koncentracijama glukoze $\left(110 \mathrm{gl}^{-1}, 160 \mathrm{gl}^{-1}\right.$ i $\left.220 \mathrm{gl}^{-1}\right)$

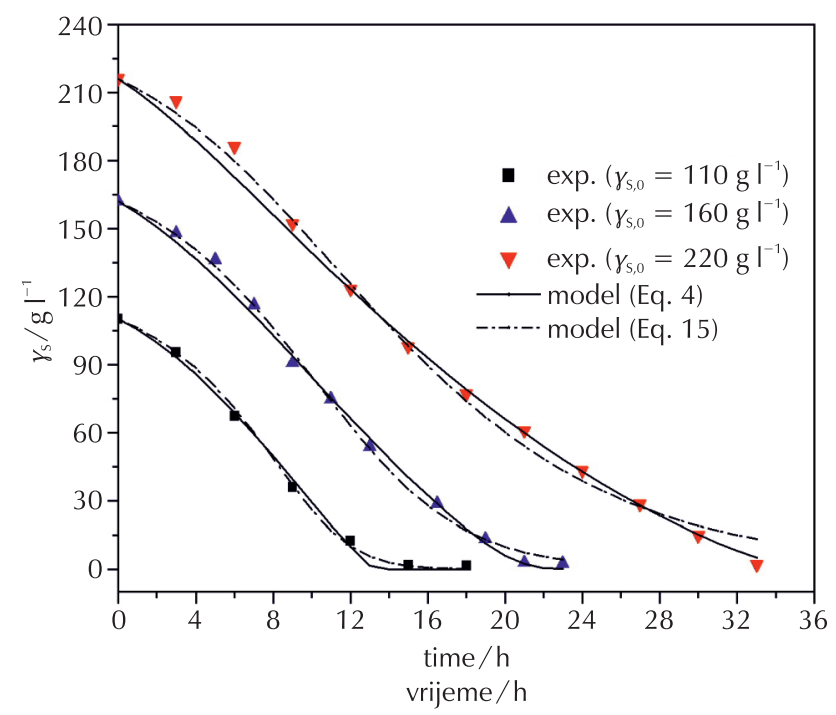

Fig. 2 - Experimental results and simulation of glucose concentration at different initial concentrations of glucose $\left(110 \mathrm{gl}^{-1}, 160 \mathrm{gl}^{-1}\right.$, and $\left.220 \mathrm{gl}^{-1}\right)$

S I ika 2 - Eksperimentalni rezultati i modeliranje koncentracije glukoze pri različitim početnim koncentracijama glukoze $\left(110 \mathrm{gl}^{-1}, 160 \mathrm{gl}^{-1}\right.$ i $\left.220 \mathrm{gl}^{-1}\right)$ 


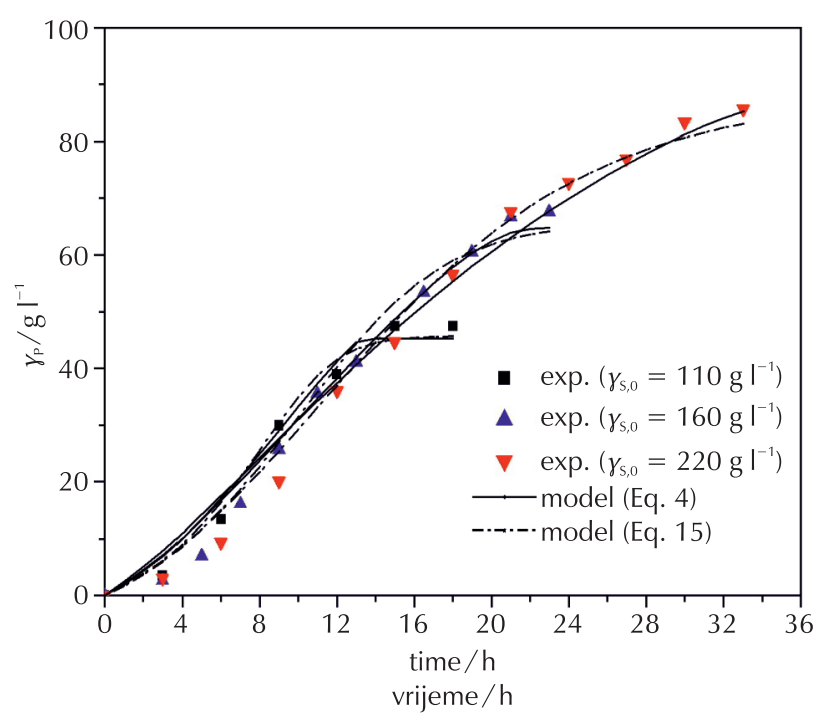

Fig. 3 - Experimental results and simulation of ethanol concentration at different initial concentrations of glucose $\left(110 \mathrm{gl}^{-1}, 160 \mathrm{gl}^{-1}\right.$, and $\left.220 \mathrm{gl}^{-1}\right)$

S I i k a 3 - Eksperimentalni rezultati i modeliranje koncentracije etanola pri različitim početnim koncentracijama glukoze $\left(110 \mathrm{gl}^{-1}, 160 \mathrm{gl}^{-1}\right.$ i $\left.220 \mathrm{gl}^{-1}\right)$

Ta ble 1 - Kinetics parameters

Tabli c a 1 - Kinetički parametri

\begin{tabular}{ccccc}
\hline & & $\gamma_{\mathrm{S}, 0}=110 \mathrm{gl}^{-1}$ & $\gamma_{\mathrm{S}, 0}=160 \mathrm{gl}^{-1}$ & $\gamma_{\mathrm{S}, 0}=220 \mathrm{gl}^{-1}$ \\
\hline & $\mu_{\max } / \mathrm{h}^{-1}$ & 0.2174 & 0.1790 & 0.1704 \\
& $K_{\mathrm{S}} / \mathrm{Ig}^{-1}$ & 19.6015 & 13.2139 & 6.5788 \\
Model & $K_{\mathrm{P}} / \mathrm{Ig}^{-1}$ & 16.7864 & 21.7157 & 23.7452 \\
A & $Y_{\mathrm{X} / \mathrm{P}}$ & 0.1467 & 0.1229 & 0.1011 \\
& $Y_{\mathrm{X} / \mathrm{S}}$ & 0.0608 & 0.0499 & 0.0414 \\
& res. $^{*}$ & 53.44 & 159.45 & 400.9077 \\
\hline & $\mu_{\max } / \mathrm{h}^{-1}$ & 0.2631 & 0.2301 & 0.2342 \\
& $k_{\mathrm{S}} / \mathrm{gl}^{-1}$ & 1.1683 & 4.6143 & 2.5230 \\
Model & $k_{\mathrm{P}} / \mathrm{gl}^{-1}$ & 40.5013 & 39.2565 & 28.1250 \\
(Eq. 4) & $\gamma_{\mathrm{P}, \max } / \mathrm{gl}^{-1}$ & 129.7881 & 128.8183 & 121.8918 \\
& $Y_{\mathrm{X} / \mathrm{P}}$ & 0.1477 & 0.1239 & 0.1027 \\
& $Y_{\mathrm{X} / \mathrm{S}}$ & 0.0606 & 0.0496 & 0.0415 \\
& res. & 74.4205 & 220.2505 & 516.2401 \\
\hline
\end{tabular}

${ }^{*}$ residue $=\sum_{i=1}^{n}\left(C_{\exp }-C_{\text {calc }}\right)^{2}$

From Table 1, it is obvious that there is no general relationship between the initial glucose concentrations and the values of $\mu_{\max }$ and $k_{\mathrm{S}}$ of model $\mathrm{B}$, due to the fact that parameters in this empirical model represent no meaningful aspects of reality. It affects the capability of this model to provide a reliable basis for optimization and further scale-up of ethanol batch fermentations process by yeast. However, in model A, the predicted values of $\mu_{\max }$ decreased with an increase in the initial glucose concentration, indicating substrate inhibition on cell growth. The values of $K_{\mathrm{s}}$, however, decreased with the increase in the initial glucose concentration suggesting that the increment of osmotic pressure of the solution caused by the high glucose concentration had a negative effect on the activity of transport protein in yeast cells, which resulted in an increase in the value of rate constant for glucose desorp- tion from transport protein $\left(r_{\mathrm{ds}}\right)$. Furthermore, the ethanol molecule is smaller than glucose and more easily adsorbed by the transport protein, therefore the increment value of $K_{\mathrm{s}}$ will lead to a decrement in $K_{\mathrm{p}}$ due to the competition between glucose and ethanol. This phenomenon is enhanced by the increase in ethanol concentration.

\section{Conclusion}

The proposed kinetic model of batch ethanol fermentation by yeast based on the irreversible adsorption mechanism could bring a revolution in the transfer of the empirical model to a physical model for fermentation kinetics, since every parameter in this model provides physical meaningful aspects of reality. Compared with the classic model, the proposed model is more practicable for the optimization of ethanol fermentation due to its higher accuracy of prediction, and less parameters involved. Furthermore, the variation in the kinetic parameters with the initial glucose concentration is obtained and represents as follows. The predicted values of $\mu_{\max }$ and $K_{\mathrm{s}}$ decreased with an increase in the initial glucose concentration, while an increment in $K_{\mathrm{p}}$ was observed.

\section{ACKNOWLEDGEMENTS}

This work was supported by the Key Technologies R \& D Program of He'nan (No. 112102310393) and the Foundation for University Key Young Teacher by the Ministry of Education of He'nan (No. 2009GGJS-052).

\section{List of symbols and abbreviations Popis simbola i kratica}

$K_{\mathrm{p}} \quad$ - adsorption equilibrium constant of ethanol, $\mathrm{Ig}^{-1}$ - adsorpcijska ravnotežna konstanta etanola, $\lg ^{-1}$

$K_{\mathrm{S}} \quad$ - adsorption equilibrium constant of glucose, $\mathrm{Ig}^{-1}$ - adsorpcijska ravnotežna konstanta glukoze, I g $^{-1}$

k $\quad$ - reaction constant, $\mathrm{h}^{-1}$

- reakcijska konstanta, $\mathrm{h}^{-1}$

$k_{\mathrm{ap}} \quad-$ ethanol adsorption constant, $\mathrm{h}^{-1}$

- adsorpcijska konstanta etanola, $\mathrm{h}^{-1}$

$k_{\mathrm{as}} \quad-$ glucose adsorption constant, $\mathrm{h}^{-1}$

- adsorpcijska konstanta glukoze, $\mathrm{h}^{-1}$

$k_{\mathrm{dP}} \quad-$ ethanol desorption constant, $\mathrm{gl}^{-1} \mathrm{~h}^{-1}$

- desorpcijska konstanta etanola, $\mathrm{gl}^{-1} \mathrm{~h}^{-1}$

$k_{\mathrm{ds}} \quad-$ glucose desorption constant, $\mathrm{gl}^{-1} \mathrm{~h}^{-1}$

- desorpcijska konstanta glukoze, $\mathrm{gl}^{-1} \mathrm{~h}^{-1}$

$k_{\mathrm{p}} \quad-$ ethanol inhibition constant, $\mathrm{gl}^{-1}$

- inhibicijska konstanta etanola, $\mathrm{gl}^{-1}$

$k_{\mathrm{S}} \quad-$ half-saturation coefficient, $\mathrm{gl}^{-1}$

- koeficijent poluzasićenosti, $\mathrm{gl}^{-1}$

$r_{\mathrm{aP}} \quad-$ ethanol adsorption rate, $\mathrm{gl}^{-1} \mathrm{~h}^{-1}$

- brzina adsorpcije etanola, $\mathrm{gl}^{-1} \mathrm{~h}^{-1}$

$r_{\mathrm{aS}} \quad-$ glucose adsorption rate, $\mathrm{gl}^{-1} \mathrm{~h}^{-1}$

- brzina adsorpcije glukoze, $\mathrm{gl}^{-1} \mathrm{~h}^{-1}$

$r_{\mathrm{dP}} \quad-$ ethanol desorption rate, $\mathrm{gl}^{-1} \mathrm{~h}^{-1}$

- brzina desorpcije etanola, $\mathrm{gl}^{-1} \mathrm{~h}^{-1}$

$r_{\mathrm{ds}} \quad-$ glucose desorption rate, $\mathrm{gl}^{-1} \mathrm{~h}^{-1}$

- brzina desorpcije glukoze, $\mathrm{gl}^{-1} \mathrm{~h}^{-1}$

$r_{\mathrm{P}} \quad-$ ethanol formation rate, $\mathrm{gl}^{-1} \mathrm{~h}^{-1}$

- brzina stvaranja etanola $\mathrm{gl}^{-1} \mathrm{~h}^{-1}$ 
$r_{\mathrm{S}} \quad-$ glucose consumption rate, $\mathrm{gl}^{-1} \mathrm{~h}^{-1}$

- brzina potrošnje glukoze, $\mathrm{gl}^{-1} \mathrm{~h}^{-1}$

$r_{\mathrm{X}} \quad-$ cell growth rate, $\mathrm{gl}^{-1} \mathrm{~h}^{-1}$

- brzina rasta stanica, $\mathrm{gl}^{-1} \mathrm{~h}^{-1}$

$Y_{\mathrm{x} / \mathrm{S}} \quad-$ yield coefficient of biomass on glucose

- koeficijent prinosa biomase na glukozi

$Y_{\mathrm{X} / \mathrm{P}} \quad-$ yield coefficient of biomass on ethanol

- koeficijent prinosa biomase na etanolu

$\gamma_{\mathrm{P}} \quad-$ ethanol concentration, $\mathrm{gl}^{-1}$

- koncentracija etanola, $\mathrm{g} \mathrm{I}^{-1}$

$\gamma_{\mathrm{s}} \quad-$ glucose concentration, $\mathrm{gl}^{-1}$

- koncentracija glukoze, $\mathrm{gl}^{-1}$

$\gamma_{\mathrm{s}, 0} \quad$ - initial glucose concentration, $\mathrm{gl}^{-1}$

- početna koncentracija glukoze, $\mathrm{gl}^{-1}$

$\gamma_{\mathrm{x}} \quad-$ cell concentration, $\mathrm{gl}^{-1}$

- koncentracija stanica, $\mathrm{gl}^{-1}$

$\theta_{\mathrm{p}} \quad-$ fractional cell surface coverage with adsorbed glucose

- pokrivenost površine stanica adsorbiranom glukozom

$\theta_{\mathrm{S}} \quad-$ fractional cell surface coverage with adsorbed ethanol

- pokrivenost površine stanica adsorbiranim etanolom

$\theta_{v} \quad-$ fractional free cell surface

- udjel slobodne površine stanica

$\mu \quad-$ specific growth rate, $\mathrm{h}^{-1}$

- specifična brzina rasta, $\mathrm{h}^{-1}$

DNS - dinitrosalicylic acid

- dinitrosalicilna kiselina

E - ethanol

- etanol

G - glucose

- glukoza

$\max -$ maximum

- maksimum

rpm - revolutions per minute

- broj okretaja u minuti

$\sigma \quad-$ transporter

- transporter

\section{References}

\section{Literatura}

1. H. Jin, R. Liu, Y. He, Kinetics of Batch Fermentations for Ethanol Production with Immobilized Saccharomyces cerevisiae Growing on Sweet Sorghum Stalk Juice, Procedia Environ. Sci. 12 (2012) 137-145, doi: http://dx.doi.org/10.1016/j. proenv.2012.01.258.
2. S. Kelkar, K. Dolan, Modeling the effects of initial nitrogen content and temperature on fermentation kinetics of hard cider, J. Food Eng. 109 (2012) 588-596, doi: http://dx.doi. org/10.1016/j.jfoodeng.2011.10.020.

3. A. B. Jarzebski, J. J. Malinowski, J. Goma, Modeling of ethanol fermentation at high yeast concentrations, Biotechnol. Bioeng. 34 (1989) 1225-1230, doi: http://dx.doi.org/10.1002/ bit.260340915.

4. Y. Tan, Z. Wang, A. C. Marshall, Modeling substrate inhibition of microbial growth, Biotechnol. Bioeng. 52 (1996) 602-608, doi: http://dx.doi.org/10.1002/(SICI)10970290(19961205)52:5<602::AID-BIT7>3.0.CO;2-N.

5. T. Ma, J. Li, G. Li, F. Liang, R. Liu, A kinetic model for bio-desulfurization by Rhodococcus sp.DS-3, J. Chem. Ind. Eng. 57 (2006) 1418-1421.

6. M. Phisalaphong, N. Sriaattana, W. Tanthapanichakoon, Mathematical modeling to investigate temperature effect on kinetic parameters of ethanol fermentation, Biochem. Eng. J. 28 (2006) 26-43, doi: http://dx.doi.org/10.1016/j.bej.2005.08.039.

7. A. D. Kroumov, A. N. Modenes, M. C. A. Tait, Development of new unstructured model for simultaneous saccharification and fermentation of starch to ethanol by recombinant strain, Biochem. Eng. J. 28 (2006) 243-255, doi: http://dx.doi. org/10.1016/j.bej.2005.11.008.

8. Z. R. Liu, S. L. Li, G. Y. Zhan, The Research Progress on Sugar Transportation of Saccharomyces cerevisiae, Food Ferment. Ind. 30 (2004) 65-69.

9. H. S. Lun, H. W. Hsu, Analysis of gas stripping during ethanol fermentation in a continuous stirred tank reactor, Chem. Eng. Sci. 45 (1990) 1289-1299, doi: http://dx.doi. org/10.1016/0009-2509(90)87121-8.

10. T. Damore, G. G. Stewart, Ethanol tolerance of yeast, Enzyme Microb. Technol. 9 (1987) 322-330, doi: http://dx.doi. org/10.1016/0141-0229(87)90053-6.

11. E. Penalver, P. Lucero, E. Moreno, R. Lagunas, Catabolite inactivation of the maltose transporter in nitrogen-starved yeast could be due to the stimulation of general protein turnover, FEMS Microbiol Lett. 166 (1998) 317-324, doi: http://dx.doi. org/10.1111/j.1574-6968.1998.tb13907.x.

12. W. Liu, D. Bratkoa, M. Prausnitzj, H. W. Blancha, Effect of alcohols on aqueous lysozyme-lysozyme interactions from static light-scattering measurements, Biophys. Chem. 107 (2004) 289-298, doi: http://dx.doi.org/10.1016/j.bpc.2003.09.012.

13. J. M. Lee, J. F. Pollard, G. A. Coulman, Ethanol fermentation with cell recycling: Computer simulation, Biotechnol. Bioeng. 25 (1983) 497-511, doi: http://dx.doi.org/10.1002/ bit. 260250215 . 


\title{
SAŽETAK
}

Kinetika fermentacije etanola temeljena na procesima adsorpcije

\author{
Z. $\mathrm{Liu}^{*}$ i X. $\mathrm{Li}$
}

Trenutačno se gotovo svi kinetički modeli fermentacije etanola temelje na Monodovoj jednadžbi. Takvi modeli se ubrajaju u iskustvene modele, pa nisu prikladni za optimizaciju i uvećanje stvarnih procesa. $U$ ovom je radu razvijen novi kinetički model fermentacije etanola na temelju mehanizma adsorpcije, u kojem svi parametri imaju određeni fizikalni smisao. Šaržnom fermentacijom s različitim početnim koncentracijama glukoze i usporedbom s postojećim modelom utvrđeno je da model ima prednost u visokoj preciznosti i manje parametara te se jednostavno regulira jer se maksimalna specifična brzina rasta $\mu_{\max }$ i adsorpcijska ravnotežna konstanta glukoze $K_{\mathrm{s}}$ smanjuju s povećanjem početne koncentracije glukoze, a povećava adsorpcijska ravnotežna konstanta etanola $K_{\mathrm{p}}$. Spomenuti model pruža novu točku gledišta za istraživanje kinetike fermentacije.

College of Chemical Engineering \& Pharmaceutics Henan University of Science and Technology 471003 Luoyang

Kina
Prispjelo 17. kolovoza 2013.

Prihvaćeno 19. studenoga 2013. 